\title{
Concept of using the heat pipes in the heat exchanger of diesel engine exhaust system intended for use in potentially explosive atmospheres
}

Limiting the temperature of exhaust gases to below $150^{\circ} \mathrm{C}$ is one of the necessary conditions for diesel engine to be used in a potentially explosive atmosphere. For this purpose heat exchangers are necessary to be used. This article presents the concept of exchanger in which heat pipes are used to transport thermal energy from the exhaust gases to the cooling medium.

Key words: exhaust system, heat exchanger, heat pipes, temperature of exhaust gases, hard coal mining

\section{Introduction}

Operation of diesel engines in the areas threatened by methane and/or coal dust explosion hazard is possible only after meeting the required technical conditions [1, 3, 4, 13]. Limitation of surface temperature as well as temperature of exhaust gases below $150^{\circ} \mathrm{C}$ are among these conditions. Diesel engines used in the areas threatened by explosion hazard most frequently have the useful power within the range from 80 to $160 \mathrm{~kW}$ [5]. As the heat transported with exhaust gases is similar to the heat transformed into useful work [8], it is necessary to collect big amount of energy from exhaust gases and then to dispersed it or to recuperate it [7].

Different types of the heat exchangers e.g. those described in $[3,6]$ are used to reduce exhaust gases temperature.

Air quality i.e. emission of pollutants by diesel drives is the other especially important aspect. In 2016 the Regulation of the European Parliament and of the Council [12] on the accepted level of harmful substances emission by mobile machines operating in a potentially explosive atmospheres was issued. The requirements can be compared with the requirements of stage IIIA of the diesel engine directive repealed by this regulation [11]. For the reasons described in $[1,3]$, diesel engines used so far by the Polish manufacturers meet the requirements of the repealed directive [11]. in the scope of the stage II and in some cases the stage IIIA.

To improve the quality of exhaust gases emitted to a potentially explosive atmosphere, the concept of outlet system, described in [3] was suggested. This article is focused on the concept of heat exchanger based on heat pipes and/or thermosiphon pipes.

\section{Heat pipes and thermosiphon pipes}

Heat pipe is a passive device of a very long lifetime [14]. Generally the heat pipe is a vacuum, tightly closed thin-wall pipe filled with capillary structures, so called wick, and partially with the working fluid. Heat pipes have a very high heat transfer coefficient from 10000 to 100000 $\mathrm{W} / \mathrm{mK}$ comparing to $400 \mathrm{~W} / \mathrm{mK}$ for copper [21]. They use two-stage, close evaporation circuit and then condensation of the working fluid. The following three zones can be distinguished in a heat pipe:
- evaporation zone - heat is delivered to this zone and evaporation of working fluid takes place,

- adiabatic zone - where there is a heat transportation between evaporation zone and condensation zone without heat exchange to atmosphere,

- condensation zone - where heat from vapour is transferred to pipe outer space, so the vapour is condensed. The condensed fluid returns to the evaporator through the wick structure by capillary action.

The phase change processes and two-phase flow circulation continue as long as the temperature gradient between the evaporator and condenser is maintained.

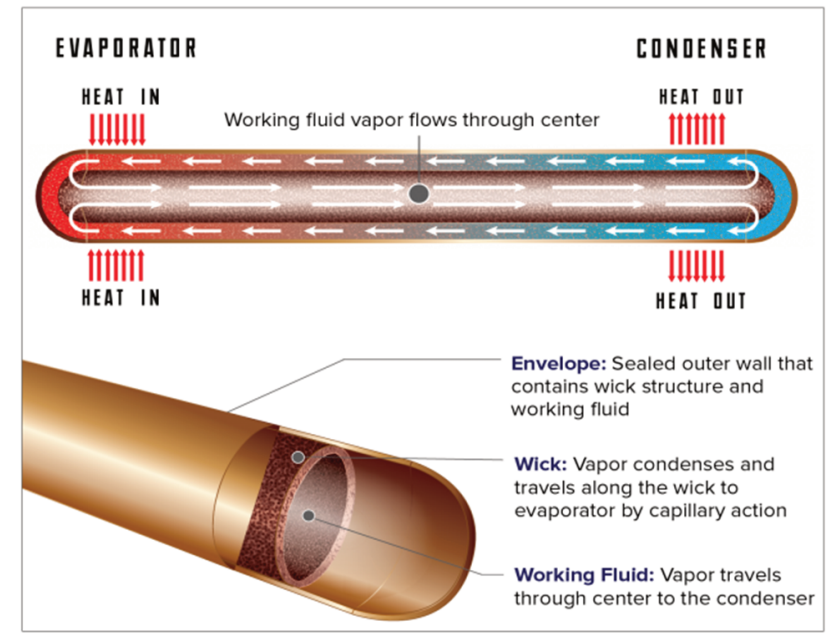

Fig. 1. Illustration of heat pipe operation [21]

Temperature range in which the heat pipes operate properly as well as their lifetime depend on a type of working fluid used and the envelope. In Table 1 sample fluids and the respective operational temperature ranges are given.

Use of heat pipes in place of homogeneous heat conductors (rods), allows to limit the dimensions and mass of heat exchangers. For instance, a heat pipe of a diameter $6 \mathrm{~mm}$, length $30 \mathrm{~cm}$, at temperature difference of $3^{\circ} \mathrm{C}$ can transfer $180 \mathrm{~W}$ of heat. To achieve the same effects using a homogeneous copper pipe of the same length, its diameter would have to be $24.4 \mathrm{~cm}$ and the weight would be around $125 \mathrm{~kg}$ [10]. 
Table 1. Working fluid with practical temperature limits [19]

\begin{tabular}{ccc}
\hline $\begin{array}{c}\text { Operating min temp., } \\
{ }^{\circ} \mathrm{C}\end{array}$ & $\begin{array}{c}\text { Operating max temp., } \\
{ }^{\circ} \mathrm{C}\end{array}$ & $\begin{array}{c}\text { Working } \\
\text { fluid }\end{array}$ \\
\hline-271 & -269 & Helium \\
-170 & 0 & Ethane \\
-150 & 40 & Propylene \\
-60 & $\sim 25$ to 100 & Methanol \\
-50 & $\sim 100$ & Acetone \\
20 & 280, short term to 300 & Water \\
100 & 350 & Naphthalene \\
200 & 300 & Dowtherm A/Therminol \\
200 & 400 & VP \\
400 & 600 & AlBr3 \\
500 & 700 & Cesium \\
600 & 1100 & Potassium \\
1100 & 1825 & Sodium \\
\hline
\end{tabular}

Thermosyphons are one of different types of heat pipes [23]. Unlike the heat pipes, which, due to the capillary structure (wick), can work at any orientation [24], thermosiphons use gravity at the return of the condensed liquid in the condenser zone. For this reason, the evaporator zone must be located below the condenser zone.

The above feature of thermosiphons may be treated as their disadvantage, however, it should also be borne in mind that by changing the orientation of a heat pipe with a wick, its possibilities in terms of the amount of transported heat change as well. The highest efficiency of the heat pipe is achieved in vertical operation when the evaporation zone is below the condenser zone. Then the return of condensed working medium from the condenser zone to the evaporator zone, in addition to the capillary forces, is supported by the force of gravity.

The superiority of thermosiphons over heat pipes should primarily include the fact that they are able to transfer higher thermal power while maintaining the same diameter, and that their length can be almost unlimited - a typical heat pipe length is $<25 \mathrm{~cm}$, while for geothermal applications thermosyphons with a length of more than $50 \mathrm{~m}$ are manufactured [24].

\section{Concept of an exhaust system and a heat exchanger for the mining diesel drive}

It is suggested to use diesel oxidation catalyst (DOC) and a diesel particulate filter (DPF) to improve quality of exhaust gases. Thanks to the use of the DOC reactor, a significant reduction of $\mathrm{CO}$ and $\mathrm{HC}$ concentrations in exhaust gases is expected (>90\%) [2].

In order to meet the safety requirements related to meeting the surface temperature limit of $150^{\circ} \mathrm{C}$, it is necessary to equip the reactor with a water jacket. On the other hand, cooling the reactor surface can reduce the efficiency of the DOC reactor. For this reason, it is suggested to apply additional air insulation between the surface of the reactor and the water jacket (Fig. 2).

The heat exchanger concept using heat pipes (Fig. 3) provides using two separate sections: the exhaust section and the cooling water section. Heat transfer between the sections will be mainly through heat pipes / thermosiphons. Due to the fact that heat pipes obtain the highest efficiency at operation, where the evaporator part is located below the condenser part, the exhaust section is provided below the cooling water section. To increase the area of heat transfer from exhaust gases, lamellas (radiators) will be placed on the pipes. In order to achieve greater efficiency in heat transfer from exhaust gases, the stream of exhaust gas and cooling water will be directed countercurrently.

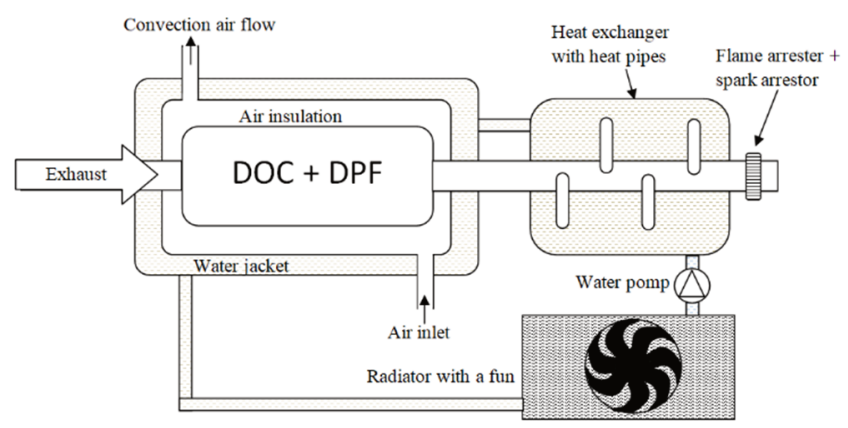

Fig. 2. Exhaust system concept with an aftertreatment system, adapted to operate in potentially explosive atmospheres

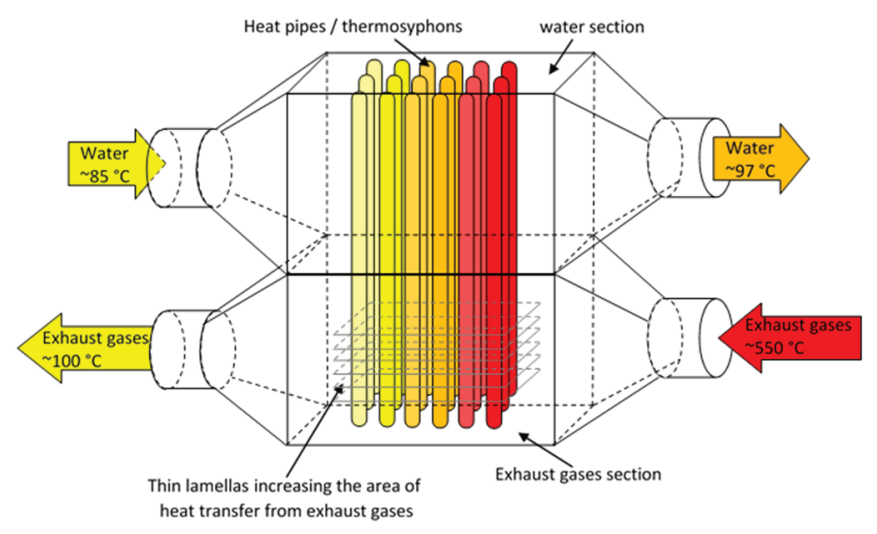

Fig. 3. Heat exchanger concept using heat pipes/thermosyphons

Number of heat pipes required for construction of the heat exchanger cooperating with an engine of maximum power $80 \mathrm{~kW}$ was assessed within the project. It was assumed the for maintaining the safety coefficient, exhaust gases should be cooled down to temperature $100^{\circ} \mathrm{C}$ (instead of limit value equal to $150^{\circ} \mathrm{C}$ ). Heat conveyed with exhaust gases can be calculated according to the following formula:

$$
\mathrm{Q}_{\mathrm{W}}=\left(\mathrm{G}_{\mathrm{F}}+\mathrm{G}_{\mathrm{A}}\right) \mathrm{c}_{\mathrm{p}}\left(\mathrm{T}_{\mathrm{H}}-\mathrm{T}_{\mathrm{L}}\right)
$$

where GF - fuel consumption per hour, GA - air consumption per hour, $c_{p}-$ specific heat of exhaust gases, $T_{H}-$ temperature of hot gases, $\mathrm{T}_{\mathrm{L}}$ - ambient temperature

Basing on [5], for determination of heat conveyed with the exhaust gases, it was assumed that $\mathrm{Q}_{\mathrm{e}} \approx \mathrm{Q}_{\mathrm{W}}\left(\mathrm{Q}_{\mathrm{e}}-\right.$ heat converted to the useful work). Temperature increase is an expected result of using the catalytic reactor in the discussed concept of exhaust system. It was assumed that temperature increase would be not greater than $80^{\circ} \mathrm{C}$ [9]. Impact of temperature increase on amount of heat conveyed with exhaust gases will be compensated by an assumption that the gases will be cooled down to $100^{\circ} \mathrm{C}$ and not to ambient temperature - constant temperatures $\mathrm{T}_{\mathrm{H}}$ and $\mathrm{T}_{\mathrm{L}}$ does not affect $\mathrm{Q}_{\mathrm{W}}$ in formula (1). 
Finally it was assumed that $\mathrm{Q}_{\mathrm{e}} \approx \mathrm{Q}_{\mathrm{w}}$ and for the discussed engine of maximum useful power $\sim 80 \mathrm{~kW}$, it was assumed that power which should be taken from exhaust gases to reduce gases temperature to $100^{\circ} \mathrm{C}$ is $\mathrm{Q}_{\mathrm{Wmax}}=80 \mathrm{~kW}$.

Expected maximum temperature of exhaust gases is $550^{\circ} \mathrm{C}$. Taking into account the fact that heat pipes operate in limited temperature range (Table 1), to cover the required temperature range from $100^{\circ} \mathrm{C}$ to $550^{\circ} \mathrm{C}$, different types of heat pipes should be used. For the discussed case, the heat pipes filled with the following liquids: Water, Naphthalene, $\mathrm{AlBr}_{3}$ (Aluminium bromide) and Caesium were selected. Most often, heat pipes manufacturers inform about the maximum conveyed power only for one engine operating point. Additionally, the available data relate only to the heat pipes filled with water or methanol. For the above reasons, the characteristics that can be obtained using the calculator for heat pipes filled with water of one of the manufacturers [22] was used for further analyses. Characteristics of heat pipe of length $400 \mathrm{~mm}$, diameter $1 / 2$ ", length of evaporator and condenser equal to $150 \mathrm{~mm}$, operating in a vertical position, where the evaporator zone is below the condenser zone, is presented in Fig. 4.

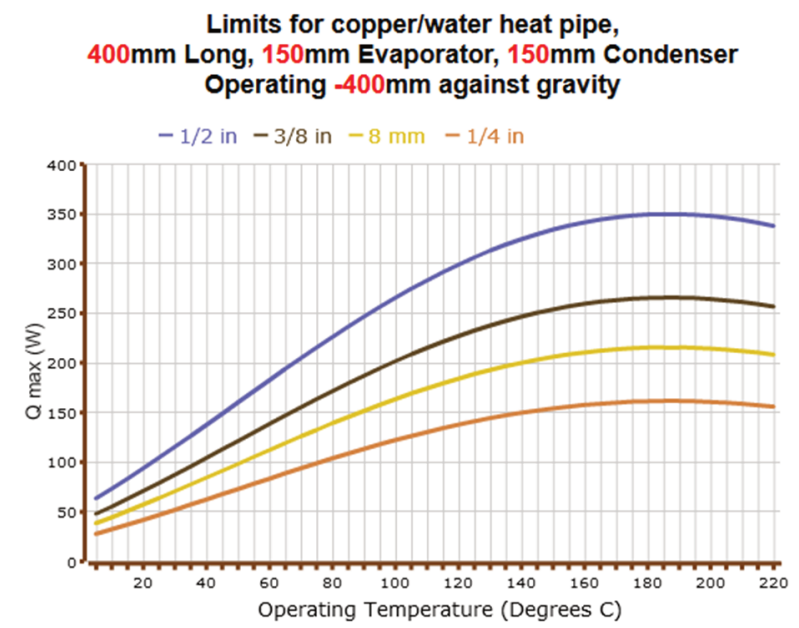

Fig. 4. Curve $\mathrm{Q}_{\max }=\mathrm{f}($ operating temperature) for a water heat pipe [22]

The above characteristics are not available for the heat pipes other than water filled ones. But, for Intermediate Temperature heat pipes the characteristic given in Fig. 5 is available.

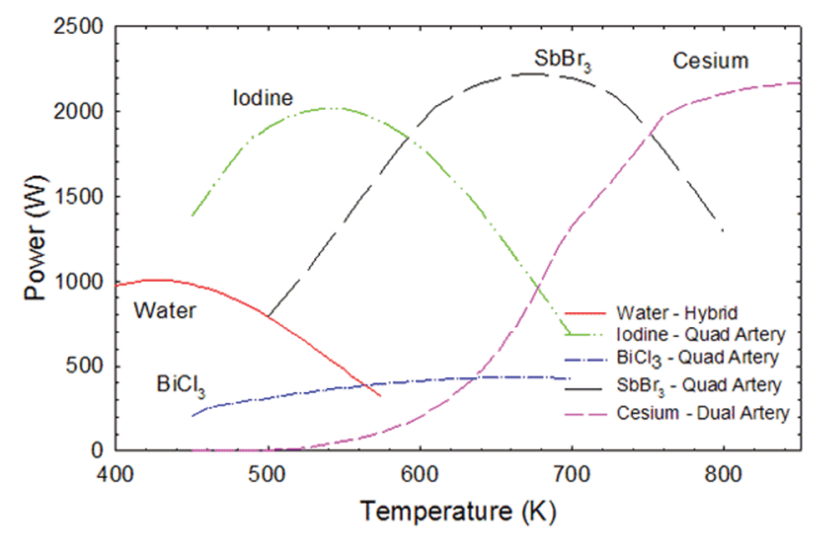

Fig. 5. Theoretical heat pipe power for different fluids [20]
Considering the fact that in the case of intermediate temperature heat pipes, the transferred power is greater than for a heat pipe filled with water, for the discussed range of operating temperatures and each of the selected heat pipes has a similar range of operation, it was assumed that for the same geometric dimensions (diameter, total length as well as size of each heat pipe zone) having an impact on transferred power, ability in heat transfer will be similar.

By transposition of the characteristics from Fig. 4 (for the pipe $1 / 2$ ") to the pipes filled with naphthalene, $\mathrm{AlBr}_{3}$ and Caesium within the operating temperatures as in Table 1, we obtain a family of characteristics presented in Fig. 5. Part of the characteristics delivered by the manufacturer [22] is drawn by a solid line. As the characteristics delivered by the manufacturer was limited to $220^{\circ} \mathrm{C}$ and the manufacturer in his information material accepts possibility of using this pipe to temperature $280^{\circ} \mathrm{C}$ (Table 1), further part of this characteristics was extrapolated using the polynomial degree 2. Extrapolated part of the characteristics for a water pipe is presented as dashed line. The relationships for other pipes were also determined by extrapolation and they were also presented as dashed lines.

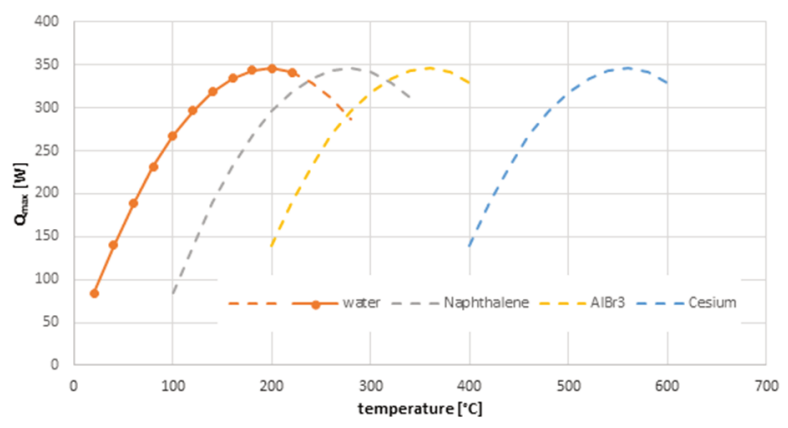

Fig. 6. Curves $Q_{\max }=f($ operating temperature) for analysing the type of working fluid

Basing of the above figure, transferred heat power was assumed depending on temperature range given in Table 2 - for the safety reason heat power values lower than those resulting from the characteristics were accepted.

Table 2. Transferred heat power depending of the working fluid and operating temperature range accepted for the analysis

\begin{tabular}{cccc}
\hline $\mathrm{T}_{1}\left[{ }^{\circ} \mathrm{C}\right]$ & $\mathrm{T}_{2}\left[{ }^{\circ} \mathrm{C}\right]$ & Working Fluid & $\mathrm{Q}[\mathrm{W}]$ \\
\hline 100 & 150 & Water & 250 \\
150 & 220 & Water & 300 \\
220 & 300 & Naphthalene & 300 \\
300 & 400 & AlBr3 & 300 \\
400 & 480 & Caesium & 150 \\
480 & $550 *$ & Caesium & 300 \\
\hline$*$ - maximum temperature of exhaust gases
\end{tabular}

Due to the fact that information on fuel burning process and air demand for the discussed engine, the product $\left(\mathrm{G}_{\mathrm{F}}+\right.$ $\left.\mathrm{G}_{\mathrm{A}}\right) * \mathrm{c}_{\mathrm{p}}$ was determined from the following relationship:

$\mathrm{Q}_{\mathrm{w}}=\left(\mathrm{G}_{\mathrm{F}}+\mathrm{G}_{\mathrm{A}}\right) \cdot \mathrm{c}_{\mathrm{p}} \cdot\left(\mathrm{T}_{\mathrm{H}}-\mathrm{T}_{\mathrm{L}}\right)$

$\mathrm{Q}_{\mathrm{w}}=80 \mathrm{~kW}$

$\mathrm{T}_{\mathrm{H}}=550^{\circ} \mathrm{C}$

$\mathrm{T}_{\mathrm{L}}=100^{\circ} \mathrm{C}$ 


$$
\left(\mathrm{G}_{\mathrm{F}}+\mathrm{G}_{\mathrm{A}}\right) \cdot \mathrm{c}_{\mathrm{p}}=178 \mathrm{~W} /{ }^{\circ} \mathrm{C}
$$

To estimate the power which should be taken from exhaust gases in each temperature range given in Table 2, the following formula was used:

$$
\mathrm{Q}_{\mathrm{wi}}=178\left(\mathrm{~T}_{2}-\mathrm{T}_{1}\right)
$$

where $T_{2}$ and $T_{1}-$ higher and lower temperature for the $i^{\text {th }}$ temperature range from Table 2 .

From the product of heat $\left(\mathrm{Q}_{\mathrm{wi}}\right)$, which should be transferred in the given temperature range as well as from heat which can be transferred by a single pipe $\left(\mathrm{Q}_{\mathrm{hp} 1}\right)$, minimum number of required pipes was calculated. Calculation results are given in Table 3 .

Table 3. Calculation results

\begin{tabular}{cccccc}
\hline $\begin{array}{c}\text { Working } \\
\text { Fluid }\end{array}$ & $\begin{array}{c}\mathrm{T}_{2} \\
{\left[{ }^{\circ} \mathrm{C}\right]}\end{array}$ & $\begin{array}{c}\mathrm{T}_{1} \\
{\left[{ }^{\circ} \mathrm{C}\right]}\end{array}$ & $\mathrm{Q}_{\mathrm{Wi}}[\mathrm{W}]$ & $\mathrm{Q}_{\mathrm{hp} 1}[\mathrm{~W}]$ & $\begin{array}{c}\mathrm{Q}_{\mathrm{Wi}} / \mathrm{Q}_{\mathrm{hp} 1} \\
{[\mathrm{pcs} .]}\end{array}$ \\
\hline Caesium & 550 & 480 & 12444 & 300 & 42 \\
Caesium & 480 & 400 & 14222 & 150 & 95 \\
AlBr3 & 400 & 300 & 17778 & 300 & 60 \\
Naphthalene & 300 & 220 & 14222 & 300 & 48 \\
Water & 220 & 150 & 12444 & 300 & 42 \\
Water & 150 & 100 & 8889 & 250 & 36 \\
& & & & 323
\end{tabular}

$\mathrm{Q}_{\mathrm{hp} 1}$ - assume power of a single heat pipe in the given temperature range [W]

$\mathrm{Q}_{\mathrm{Wi}} / \mathrm{Q}_{\mathrm{hp} 1}$ - number of pipes of the given type [pcs]

\section{Safety}

Safety is the most important aspect, especially in the underground coal mining industry. In connection with the above, the safety solutions should be taken into account. Heat pipes do not pose any danger if proper operate. However, in the risk analysis, also emergency states should be considered. This is particularly important for the pipes where substances such as water are used as a working fluid. Unsealing of the tube, e.g. as in a result of vibrations during operation is the main risk that can happen. As a result of leakage of the tube, the working fluid may escape to the atmosphere if the leakage is in the exhaust section, and / or to the cooling medium, if the leakage is in the water section. Hazard statements being a part of Globally Harmonized System of Classification and Labelling of Chemicals
(GHS) [16] are used for assessment of hazards resulting from chemical substances or their mixtures. In Table 4, the hazards posed by each working fluid used in the discussed

\begin{tabular}{|c|c|}
\hline $\begin{array}{l}\text { Working } \\
\text { Fluid }\end{array}$ & Hazards \\
\hline \multirow{2}{*}{$\begin{array}{l}\text { Caesium } \\
\text { [15] }\end{array}$} & $\begin{array}{l}\text { H260 - During a contact with water self-ignited flam- } \\
\text { mable gases are released. }\end{array}$ \\
\hline & H314 - Causes a serious skin burns and injuries to eyes. \\
\hline \multirow{3}{*}{ AlBr3 [18] } & H314 - Causes a serious skin burns and injuries to eyes. \\
\hline & EUH014 - Reacts violently with water. \\
\hline & In the result of hydrolysis, $\mathrm{HBr}$ is released. \\
\hline \multirow{2}{*}{$\begin{array}{l}\text { Naphtha- } \\
\text { lene [17] }\end{array}$} & $\mathrm{H} 228$ - flammable in the solid state \\
\hline & $\begin{array}{l}\text { H410 - Is very toxic to water organisms, causing long- } \\
\text { lasting effects. }\end{array}$ \\
\hline
\end{tabular}
heat pipes, are listed.

\section{Conclusions}

The article presents the concept of exhaust gases outlet system. The expected benefits of the presented concept are as follows:

- significant reduction of $\mathrm{CO}, \mathrm{HC}$ emission with exhaust gases $(>90 \%)$,

- smaller dimensions of the heat exchanger used for cooling the exhaust gases,

- lower weight of the entire exhaust system.

Heat pipes have much greater heat transfer power comparing to solid conductors of the same dimensions. This is why their use is a very attractive option in relation to the current solutions.

For the safety reason, use of the pipes filled with other fluid than water, exclude them from using in underground mine workings.

In further research work the analysis of using the waterfilled heat pipes to increase the efficiency of the currently used heat exchangers, e.g. for dissipation of the coolant heat, is considered.

The use of thermosiphons instead of the analysed heat pies enables a reduction in the number of the required pipes.

Due to the lack of characteristics of power transferred in heat pipes and thermosiphons in a function of temperature, further tests are planned to determine them.

\section{Bibliography}

[1] DOBRZENIECKI, P. Dostosowanie silnika spalinowego z układem wtryskowym common rail górniczej maszyny roboczej do obowiązujących wymagań i przepisów. Maszyny Górnicze. 2016, 3, 45-53.

[2] KRUCZYŃSKI, S., DANILCZYK, W. Ograniczanie szkodliwości gazów wylotowych silników spalinowych poprzez zastosowanie reaktorów katalitycznych. MOTROL, 2007, 9 , 93-102.

[3] LESIAK, K., BRZEZANSKI, M. Concept of the exhaust system of combustion engines used in underground mining. Combustian Engines. 2017, 169(2), 97-100. DOI: 10.19206/ CE-2017-217

[4] PIECZORA, E., DOBRZANIECKI P. About requirements for diesel drives used in hard coal mine underground work- ings. Minig - Informatics, Automation And Electrical Engineering. 2018, 2, 31-48.

[5] PIECZORA, E., DOBRZANIECKI, P., KACZMARCZYK, K., SUFFNER, H. Rozwój dołowych maszyn transportowych z napędem spalinowym. Maszyny Górnicze. 2016, 2, 20-33.

[6] SUFNER, H. Chłodzenie spalin w górniczych napędach spalinowych dla kopalń węgla kamiennego. Maszyny Górnicze. 2018, 3, 67-80.

[7] ŚWIDER, J., WOSZCZYŃSKI, M., STANKIEWICZ, K. Integracja i zarządzanie działaniem źródeł i odbiorników prądu w pojazdach z układami rekuperacji energii cieplnej. Maszyny Górnicze, 2013, 4, 10-19. 
[8] WALENTYNOWICZ, J. Wyznaczanie bilansu cieplnego silnika spalinowego o zapłonie samoczynnym. Biuletyn WAT VOL. LV. 2006, 2, 265-277.

[9] LEPREUX, O. Model-based temperature control of a diesel oxidation catalyst. Mathematics. Ecole Nationale Sup'erieure des Mines de Paris. 2009.

[10] YUNUS CENGEL, A. Heat transfer - a practical approach, Mcgraw-Hill, 2nd edition, 2002.

[11] Commission Directive 2012/46/EU of 6 December 2012 amending Directive 97/68/EC of the European Parliament and of the Council on the approximation of the laws of the Member States relating to measures against the emission of gaseous and particulate pollutants from internal combustion engines to be installed in non-road mobile machinery.

[12] Regulation (EU) 2016/1628 of the European Parliament and of the Council of 14 September 2016 on requirements relating to gaseous and particulate pollutant emission limits and type-approval for internal combustion engines for non-road mobile machinery, amending Regulations (EU) No 1024/ 2012 and (EU) No 167/2013.

Krzysztof Lesiak, MEng. - KOMAG Institute of Mining Technology.

e-mail:klesiak@komag.eu

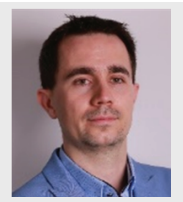

Prof. Dariusz Prostański, DSc., DEng. -KOMAG Institute of Mining Technology.

e-mail:dprostanski@komag.eu
[13] EN 1679-1:1998+A1:2011 Reciprocating internal combustion engines. Safety. Compression ignition engines.

[14] https://www.1-act.com/innovations/heat-pipe-materialsworking-fluids-and-

compatibility $/$ ?hilite $=\% 27$ luiqid $\% 27 \% 2 \mathrm{C} \% 27$ material $\% 27$

[15] https://en.wikipedia.org/wiki/Caesium

[16] https://en.wikipedia.org/wiki/GHS_hazard_statements

[17] https://en.wikipedia.org/wiki/Naphthalene

[18] https://pl.wikipedia.org/wiki/Bromek_glinu

[19] https://www.1-act.com/compatible-fluids-and-materials/

[20] https://www.1-act.com/innovations/heat-pipe-materialsworking-fluids-and-compatibility/intermediate-temp-heatpipes/

[21] https://www.1-act.com/innovations/heat-pipes/

[22] https://www.1-act.com/resources/heat-pipe-calculator/

[23] https://www.1-act.com/resources/heat-pipefundamentals/different-types-of-heat-pipes/

[24] https://www.1-act.com/resources/heat-pipefundamentals/different-types-of-heat-pipes/thermosyphons/

Prof. Marek Brzeżański, DSc., DEng. - Faculty of Mechanical Engineering, Cracow University of Technology.

e-mail: mbrzez@pk.edu.pl
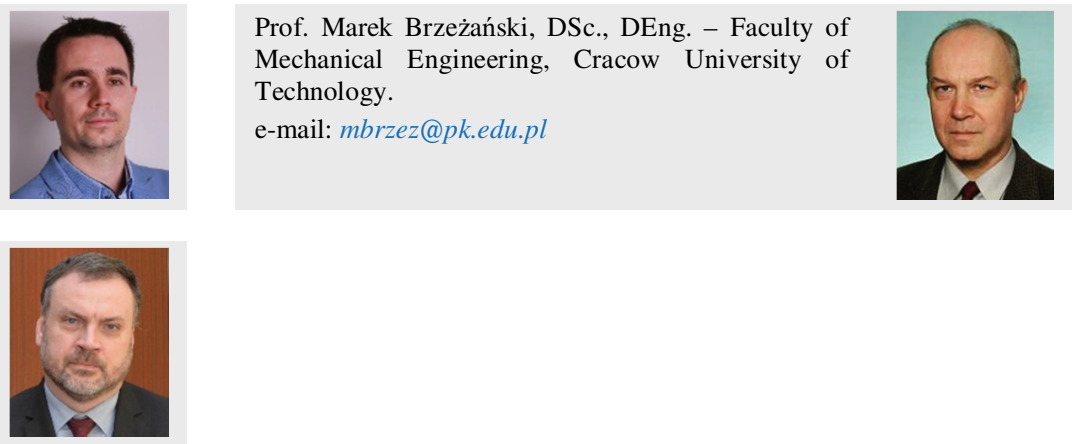